\title{
Early Neurologic Outcome and EEG of Infants with Bacterial Meningitis
}

\author{
Adrián Poblano and Carmina Arteaga \\ ${ }^{1}$ Laboratory of Cognitive Neurophysiology, \\ National Institute of Rehabilitation, Mexico City, \\ ${ }^{2}$ Clinic of Sleep Disorders, National University of Mexico, Mexico City, \\ Mexico
}

\section{Introduction}

Newborn infants (especially premature infants) are susceptible to bacterial infections and may develop primary meningitis or suffer a bacterial attack-associated neuroinfection. ${ }^{1}$ Bacterial meningitis in newborns infants remains as a serious disease with significant longterm neurological morbidity. ${ }^{2-5}$ Prediction of outcome is important in decision-making to provide information to parents, and for identification of subjects requiring close intervention and early follow-up. Clinical evaluation includes neurological examination, cerebrospinal fluid (CSF) culture, neuroimaging studies and neurophysiological studies, such as the electroencephalogram (EEG) and evoked potentials.

Neonatal bacterial meningitis continues to be a serious disease with an unchanging rate of adverse outcome of $20-60 \%$, despite a worldwide decline in mortality. The 3 major pathogens in developed countries are: Group B Streptococcus, gram negative rods and Lysteria monocytogenes. Signs and symptoms of meningitis may be subtle, unspecific, vague, atypical or absent. In order to exclude neonatal meningitis, all infants with proven or suspected sepsis should undergo lumbar puncture. Positive culture of cerebrospinal fluid may be the only way to diagnose meningitis and to identify the pathogen, as CSF parameters smay be normal at early stages and meningitis may occur frequently (up to $30 \%$ of cases) in the absence of bacteraemia. When meningitis is suspected, treatment must be aggressive, as the goal is to achieve bactericidal concentration of antibiotics and to sterilize CSF as soon as possible. Antibiotics should be administered intravenously, at the highest clinically validated doses. Empiric antibiotic treatment should include agents active against all main pathogens; currently the recommended empiric treatment of meningitis is ampicillin, plus an aminoglycoside and a third-generation cephalosporin. Therapy should be reassessed after cultures and antibiotic susceptibility is available. Prevention of neonatal sepsis, early recognition of infants at risk, prompt treatment and future adjunctive therapies will improve prognosis. ${ }^{6}$

In the newborn, EEG provides an extremely useful non-invasive test for brain function. The degree of background activity abnormality has proved to be a predictor of long-term neurologic outcome. ${ }^{7}$ Our goal, in this chapter was to show the contribution of neonatal EEG and its correlation with the neurological examination during the first year of life in clinical follow-up (at age 9 month) of newborns with bacterial neonatal meningitis. ${ }^{8}$ 


\section{Neurologic assessment and follow-up}

Twenty seven patients were studied: average maternal age at the birth of the infant was $27.59 \pm 5.41$ years (range, 17-39 years). Fourteen mothers $(50 \%)$ had one previous gestation, for seven mothers (25\%) it was the first pregnancy, and the remaining mothers had two or more gestations (25\%). Two infants (7\%) were born vaginally and $25(92 \%)$ by cesarean section.

Fifteen infants were male (55\%) and 12 female (44\%). Clinical characteristics of infants are shown in Table 1 . Fourteen infants $(51 \%)$ were born at age $<32$ weeks of gestation (wG), 10 between 32 and 36 wG (37\%) and three with 37 or more wG (11\%). Sixteen subjects $(59 \%)$ had birthweight $<1,500 \mathrm{~g}$, eight were between 1501 and $2500 \mathrm{~g}(29 \%)$, and three $(11 \%)$ infants weighed 2,501 g or more at birth. Height at birth ranged from 26 and $50 \mathrm{~cm}$, while cephalic perimeter had a range of between 24 and $39.3 \mathrm{~cm}$. Apgar score at 1 min (Apgar 1) ranged between 2 and 8, and 5-min Apgar (Apgar 5) score had a range of between 4 and 9, and Silverman-Andersen score ranged between 5 and 2 .

\begin{tabular}{|c|c|c|}
\hline Feature & Average & SD \\
\hline Age at birth (weeks) & 31.70 & 3.98 \\
\hline Weight at birth (g) & 1504 & 722 \\
\hline Height at birth $(\mathrm{cm})$ & 39.12 & 5.81 \\
\hline Cephalic perimeter $(\mathrm{cm})$ & 29.20 & 4.01 \\
\hline Apgar 1 & 5.44 & 2.25 \\
\hline Apgar 5 & 8.03 & 1.40 \\
\hline Silverman-Andersen & 3 & 1 \\
\hline
\end{tabular}

SD. Standard deviation

Table 1. Clinical features of infants with neonatal bacterial meningitis

Bacterial cultures reported Staphylococcus aureus and Staphylococcus coagulase-negative in seven cases of each (25\%). Group B Streptococcus was positive in four subjects (14\%), Group D Streptococcus was positive in two cases $(7 \%)$, and different bacteria in each of the seven remaining cases $(3 \%)$. Antibiotic treatment included a combination of vancomycin-cephotaxim in 20 subjects (74\%), vancomycine alone in four (14\%) and an ampicillin-amikacin combination in three cases $(11 \%)$. Average hospitalization days was $54.4 \pm 29.4$ days with range of 10-120 days.

EEG recordings during neonatal period were normal in nine patients (one third of the sample, $9 / 27$ of patients), while eight were mildly abnormal $(8 / 27)$, nine were moderately abnormal (9/27), and one was markedly abnormal (1/27). Clinical characteristics comparison of infants by EEG alteration severity detected differences in Apgar 5 score 
between groups, and post-hoc analyses revealed that infants with moderately and markedly abnormality had significantly lower scores $(p=0.005)$. Amiel-Tison neurological examination $^{9}$ was performed in 26 infants at 3 and 6 months of age, and in 27 infants at age 9 months; results are show in Table 2.

\begin{tabular}{|c|c|c|c|c|c|}
\hline \multirow[t]{2}{*}{$\begin{array}{l}\text { Age } \\
\text { (months) }\end{array}$} & \multicolumn{2}{|c|}{$\begin{array}{l}\text { Cephalic } \\
\text { perimeter }\end{array}$} & \multirow{2}{*}{$\begin{array}{l}\text { Reflexes } \\
\text { (n/ abn) }\end{array}$} & \multirow{2}{*}{$\begin{array}{l}\text { Passive tone } \\
(\mathrm{n} / \mathrm{abn})\end{array}$} & \multirow{2}{*}{$\begin{array}{l}\text { Active tone } \\
(\mathrm{n} / \mathrm{abn})\end{array}$} \\
\hline & $(\mathrm{n} / \mathrm{ab}$ & ) $x(S D) \mathrm{cm}$ & & & \\
\hline $3(26)$ & $24 / 2$ & $37.3(1.4)$ & $8 / 18$ & $16 / 10$ & $14 / 12$ \\
\hline $6(26)$ & $25 / 1$ & $40.7(1.6)$ & $12 / 14$ & $15 / 11$ & $16 / 10$ \\
\hline $9(27)$ & $23 / 4$ & 42.8 (1.7) & $13 / 14$ & $17 / 10$ & $22 / 5$ \\
\hline
\end{tabular}

$\mathrm{n}=$ normal, $\mathrm{abn}=$ abnormal $\mathrm{x}=$ average, $\mathrm{SD}=$ standard deviation, $\mathrm{cm}=$ centimeters

Table 2. Neurological examination results (in percentages) in infants with neonatal bacterial meningitis

No statistical differences were found when overall results were compared from both the Amiel-Tison neurologic examination and neonatal EEG $(p=0.08)$. Significant association was found between neonatal EEG result and cephalic perimeter alteration at 3, 6, and 9 months using normative data from our country 10 (Wald score $=11.40,9.96$, and 10.42; $p=$ $0.001,0.002$, and 0.001 respectively) and active tone at 9 months (Wald score $=8.94 ; p=$ 0.003 ). EEG sensitivity and specificity for predicting change in neurologic examination at 9 months of age were $72 \%$ and $44 \%$ respectively.

CT was performed in two infants and both studies were abnormal. Magnetic resonance imaging (MRI) was performed in one patient who had abnormal result. US studies were abnormal in eight subjects (30\%), abnormalities found included intraventricular hemorrhage in five patients $(18 \%)$, and periventricular leukomalacia and hydrocephalous in three subjects each $(11 \%)$.

\section{Comments}

We found that an EEG performed in the neonatal period during acute bacterial meningitis predicts adverse outcome early within the first year of life. Few studies have examined the value of neonatal EEG as a prognostic tool in patients with bacterial neuroinfection.

Watanabe et al.11 studied EEG-polygraphically in 29 newborns with meningitis, and visual and auditory evoked potentials were also obtained in some infants: clinical findings correlated with outcomes. The authors commented that EEG background activity was a good prognostic tool but could not indicate complication type, although persistent abnormalities correlated with severe brain injury. Unfortunately, this study included infants without culture-proved meningitis.

Chequer et al. ${ }^{12}$ retrospectively studied 29 infants with culture-proven meningitis. They found that degree of EEG background activity abnormality proved to be a good predictor of 
long-term neurologic outcome. Infants with normal or mildly abnormal EEG have normal outcomes, whereas those with markedly abnormal EEG died or manifested severe neurologic damage at follow-up.

Klinger et al. ${ }^{13}$ studied 37 infants during the neonatal period and 21 had adverse outcomes; nine died and 12 infants had moderate to severe disability at 1 year of age. EEG background activity and overall EEG description were identified as predictors of adverse outcome; multivariate analysis indicated that the latter was a stronger predictor, with sensitivity of $88 \%$ and specificity of $90 \%$. Infants with normal or mildly abnormal EEG had good outcomes, whereas those with moderate to markedly abnormal EEG died or survived with neurologic sequelae. Our data are in agreement with these latter results, although we found lower values of sensitivity and specificity.

Recently, ter Horst et al., ${ }^{14}$ carried-out Amplitude integrated EEG (aEEG), recordings in 22 infants with sepsis/meningitis, cases were retrospectively evaluated. Mean gestational age was 38 weeks (range: $34-42$ weeks). Thirteen infants had meningitis. Survivors were seen for neurological follow-up. Four infants died, two were severely abnormal at 24 months. Amplitude integrated EEG background pattern, sleep-wake cycling (SWC) and electrographic seizure activity (EA) were analyzed. All infants with continuous low voltage or flat trace on aEEG $(n=4)$ had an adverse outcome. Low voltage aEEGs $(n=9)$ had a positive score for an adverse outcome at $6 \mathrm{~h}$ and at $24 \mathrm{~h}$ after admission. EA was more frequent in infants with adverse outcome and had a positive score for adverse outcome. SWC appeared more frequent in infants with good outcome. In conclusion, authors found that low voltage background pattern, SWC and EA on aEEG were helpful to predict neurological outcome in infants with neonatal sepsis or meningitis.

Etiologic agents found in our infants sample are in agreement and in partial agreement with those of other studies carried out at other NICUs in Mexico City, 15,16 but are not in total agreement with other studies performed elsewhere.4,17 Thus any consideration with regard to differences in neurological outcomes related with specific bacterial agents must be performed carefully, more research is necessary in the future with larger number of patients and with multicenter samples with clinical, neurophysiological, neuroimaging and microbiological techniques to answer this question.

Correlation between EEG results and results concerning cephalic perimeter and active tone on the neurological examination were reported here and deserve greater attention. Correlation between Amiel-Tison examination and outcomes with other methods such as US, EEG, and cerebral function monitoring at 12-15 months of age was reported as good. The sensitivity to detect neurological abnormalities with various techniques is variable. Sensitivity for detecting infants with abnormal brain US was 0.97, whereas with EEG 0.89, and with cerebral function monitoring 0.88.18 Thus combined EEG examination with the clinical Amiel-Tison neurological examination and other techniques augments probability of detection of early brain damage.

A significant relation between Apgar 5 with severity of EEG abnormalities was found. This finding underlines additive effects of early adverse conditions at birth in infants with central nervous system infection; this point has been observed in many diseases, such as posthemorrhagic hydrocephalus, and apnea in infants.19,20 We suggest that clinicians and investigators must perform a multivariate weighting of each risk-factor, neurological 
examination, neurophysiologic, and neuroimage studies, for prediction of neurological sequelae in infants with neonatal bacterial meningitis.

Our patients survived during the acute phase of neuroinfection and during the 9-month follow-up; therefore disease severity could be less than infants in the samples of Watanabe et al. ${ }^{11}$, Chequer et al. ${ }^{12}$, Klinger et al. ${ }^{13}$, and ter Horst et al. ${ }^{14}$ Infants with normal or mildly abnormal EEG survived without sequelae, and those with moderately and markedly abnormal activity were neurologically abnormal at follow-up. EEG abnormalities included an infant with burst-supression, and others with slowing of background activity, spikes and slow waves. Seizures occurred in some of these infants, others had intraventricular bleeding-related hydrocephalous in which ventriculo-peritoneal shunt placement was performed and were under control during follow-up period.

\section{Conclusion}

In conclusion, it is our recommendation that EEG recording be obtained early in acute phase of the neuroinfection, because neonatal EEG is useful for predicting abnormalities in cephalic perimeter and active tone at 9 months of age in infants with bacterial neonatal meningitis.

\section{References}

[1] Meade RH. Bacterial meningitis in the neonatal infant. Med Clin North Am 1985;69:257267.

[2] Bedford H, de Louvois J, Halket S, Peckham C, Hurley R, Harvey D. Meningitis in infancy in England and Wales: follow-up at age 5 years. BMJ 2001;323:1-5.

[3] Jiang ZD, Liu XY, Wu YY, Zheng MS, Liu HC. Long-term impairments of brain and auditory functions of children recovered from purulent meningitis. Dev Med Child Neurol 1990;32:473-480.

[4] Stevens P, Eames M, Kent A, Halket S, Holt D, Harvey D. Long term outcomes of neonatal meningitis. Arch Dis Child Fetal. Neonatal Ed 2003;88:F179-F184.

[5] Wheater M, Rennie JM. Perinatal infection is an important risk factor for cerebral palsy in very-low-birthweight infants. Dev Med Child Neurol 2000;42:364-367.

[6] Berardi A, Lugli L, Rossi C, China MC, Vellani G, Contiero R, Calanca F, Camerlo F, Casula F, di Carlo C, Rossi MR, Chiarabini R, Ferrari M, Minniti S, Venturelli C, Silvestrini D, Dodi I, Zuchinni A, Ferrari F, Infezioni da Streptocco B della regione Emilia Romagna. Neonatal bacterial meningitis. Minerva Pediatr 2010;62:51-54.

[7] Garza-Morales S, Poblano-Luna A. The abnormal electroencephalogram in the newborn (in Spanish). In: Gil-Nagel A, Parra J, Iriarte J, Kanner AM. Handbook of electroencephalography. Madrid, McGraw Hill-Interamericana. 2002.pp.117-130.

[8] Poblano A, Gutiérrez R. Correlation between the neonatal EEG and the neurological examination in the first year of life in infants with bacterial meningitis. Arq Neuropsiquiatr 2007;65:576-580.

[9] Amiel-Tison C. Update of the Amiel-Tison neurologic assessment for the term neonate or at 40 weeks corrected age. Pediatr Neurol 2002;27:196-212.

[10] Ramos-Galván R. Pediatric somatometry. Follow-up study in infants and children from Mexico City (in Spanish). Arch Invest Med 1975;6, suppl 1:83-396. 
[11] Watanabe K, Hara K, Hakamada S, Kuroyanagi M, Kuno K, Aso K. The prognostic value of EEG in neonatal meningitis. Clin Electroencephalogr 1983;14:67-77.

[12] Chequer RS, Tharp BS, Dreimane D, Hahn JS, Clancy RR, Coen RW. Prognostic value of EEG in neonatal meningitis: retrospective study of 29 infants. Pediatr Neurol 1992;8:417-422.

[13] Klinger G, Chin CN, Otsubo H, Beyene J, Perlman M. Prognostic value of EEG in neonatal bacterial meningitis. Pediatr Neurol 2001;24:28-31.

[14] ter Horst HJ, van Olffen M, Remmelts HJ, de Vries J, Boss AF. The prognostic value of amplitude integrated EEG in neonatal sepsis and/or meningitis. Acta Paediatr 2010;99:194-200.

[15] Reyna-Figueroa J, Ortiz-Ibarra FJ, Plazola-Camacho NG, Limón-Rojas AE. Bacterial meningitis in newborns. Experience of the National Institute of Perinatology from 1990-1999 (in Spanish). Bol Med Hosp Infant Mex 2004;61:402-411.

[16] Rios-Reategui E, Ruiz-Gonzalez L, Murguia-de-Sierra T. Neonatal bacterial meningitis in a third level care unit (in Spanish). Rev Invest Clin 1998;50:31-36.

[17] Harvey D, Holt DE, Bedford H. Bacterial meningitis in the newborn: a prospective study of mortality and morbidity. Sem Perinatol 1999;23:218-225.

[18] Paro-Panjan D, Neubauer D, Kodric J, Bratanic B. Amiel-Tison Neurological Assessment at term age: clinical application, correlation with other methods, and outcome at 12 to 15 months. Dev Med Child Neurol 2005;47:16-26.

[19] Robles P, Poblano A, Hernández G, Ibarra J, Guzmán I, Sosa J. Cortical, brainstem and autonomic nervous system dysfunction in infants with post-hemorrhagic hydrocephalous. Rev Invest Clin 2002;54:133-138.

[20] Poblano A, Márquez A, Hernández G. Apnea in infants. Ind J Pediat 2006;73:1085-1088. 


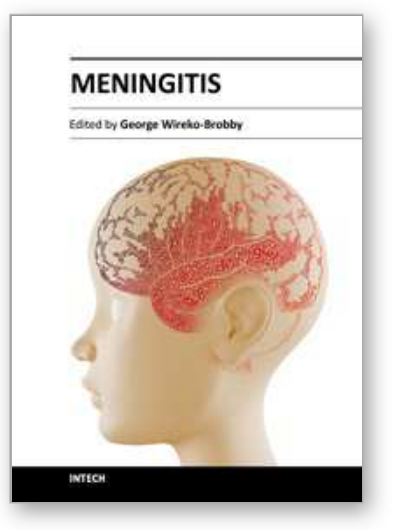

\author{
Meningitis \\ Edited by Prof. George Wireko-Brobby
}

ISBN 978-953-51-0383-7

Hard cover, 232 pages

Publisher InTech

Published online 30, March, 2012

Published in print edition March, 2012

Meningitis is a medical emergency requiring a rapid diagnosis and an immediate transfer to an institution supplied with appropriate antibiotic and supportive measures. This book aims to provide general practitioners, paediatricians, and specialist physicians with an essential text written in an accessible language, and also to highlight the differences in pathogenesis and causative agents of meningitis in the developed and the developing world.

\title{
How to reference
}

In order to correctly reference this scholarly work, feel free to copy and paste the following:

Adrián Poblano and Carmina Arteaga (2012). Early Neurologic Outcome and EEG of Infants with Bacterial Meningitis, Meningitis, Prof. George Wireko-Brobby (Ed.), ISBN: 978-953-51-0383-7, InTech, Available from: http://www.intechopen.com/books/meningitis/early-neurologic-outcome-and-eeg-of-infants-with-bacterialmeningitis

\section{INTECH}

open science | open minds

\section{InTech Europe}

University Campus STeP Ri

Slavka Krautzeka 83/A

51000 Rijeka, Croatia

Phone: +385 (51) 770447

Fax: +385 (51) 686166

www.intechopen.com

\section{InTech China}

Unit 405, Office Block, Hotel Equatorial Shanghai

No.65, Yan An Road (West), Shanghai, 200040, China 中国上海市延安西路65号上海国际贵都大饭店办公楼405单元

Phone: +86-21-62489820

Fax: +86-21-62489821 
(C) 2012 The Author(s). Licensee IntechOpen. This is an open access article distributed under the terms of the Creative Commons Attribution 3.0 License, which permits unrestricted use, distribution, and reproduction in any medium, provided the original work is properly cited. 